\title{
IMPLEMENTASI PENDIDIKAN KARAKTER DISIPLIN PADA PESERTA DIDIK DI SD NEGERI 187/1 TERATAI
}

\author{
Drs. Faizal Chan S,Pd.,M.Si ${ }^{1}$, Agung Rimba Kurniawan S,Pd.,M.Pd ${ }^{2}$, Lia Gusti Melinda ${ }^{3}$, \\ Rattu Priantini $^{4}$, Zubaedah ${ }^{5}$, Siti Reni Suharti ${ }^{6}$, Siti Khodijah ${ }^{7}$ \\ 1, 2, 3, 4, 5, 6, 7 Pendidikan Guru Sekolah Dasar FKIP Universitas Jambi \\ e-mail: liagustipgsd@gmail.com
}

\begin{abstract}
This study aims to determine and describe the implementation of discipline character education for students in elementary schools. Discipline character is one of the character values that are in the core competencies of social attitudes that must be developed in both students. This study uses a qualitative research approach. This type of research is descriptive research. This research was carried out in Teratai Muara Bulian Elementary School 187/1. This research was conducted in a period of two months (August - September). Data and data sources used are primary data and secondary data. Data sources taken in this study are 1) observation data, 2) school principal data, 3) teacher data, 4) student data. The technique of sample collection in this study was purposive sampling. Data collection techniques, namely 1) observation, observation used is non-participant observation. 2) interview, the interview used is a structured interview. Interviews were conducted with the school principal and class teacher. Data analysis using military and Huberman analysis techniques. Activities in data analysis, namely data reduction, data display (data presentation), and data conslusion (drawing conclusions). This research instrument is based on two sources, according to the Ministry of National Education (2010: 26) indicators of the value of discipline are: "1) getting used to being present on time; 2) getting used to obey the rules; and 3) using clothes in accordance with the provisions "and according to Syafrudin (Muhammad Khafid and Suroso, 2007: 91) are:" 1) observance of study time; 2) observance of lesson assignments; 3) obedience using the time of coming and going home ". The results showed that the implementation of discipline character education in SD N 187/1 Lotus lotus estuary was carried out adequately. The results obtained are related to the discipline value indicator.
\end{abstract}

Keywords: Education Character, Disciplined Character, Student

\begin{abstract}
ABSTRAK
Penelitian ini bertujuan untuk mengetahui dan mendeskripsikan implementasi pendidikan karakter disiplin peserta didik di Sekolah Dasar. Karakter disiplin merupakan salah satu nilai karakter yang ada di dalam kompetensi inti sikap sosial yang harus dikembangkan kedapa peserta didik. Penelitian ini menggunakan pendekatan penelitian kualutatif. Jenis penelitian ini adalah penelitian deskriptif. Penelitian ini dilaksanakan di SD Negeri 187/1 Teratai Muara Bulian. Penelitian ini dilaksanakan dalam jangka waktu dua bulan (agustus - september). Data dan sumber data yang digunakan adalah data primer dan data sekunder. Sumber data yang diambil dalam penelitian ini yaitu 1) data observasi, 2) data kepala sekolah, 3) data guru, 4) data peserta didik. Teknik pengumpulan sampel penelitian ini yaitu purposive sampling. Teknik pengumpulan data, yaitu 1) observasi, observasi yang digunakan adalah observasi non partisipan. 2) wawancara, wawancara yang digunakan adalah wawancara terstruktur. Wawancara dilakukan dengan kepala sekolah dan guru kelas. Analisis data menggunakan teknik analisis miler dan Huberman. Aktivitas dalam analisis data, yaitu data reduction, data display (penyajian data), dan data conslusion (penarikan kesimpulan). Instrumen penelitian ini berdasarkan dua sumber, yaitu menurut kemendiknas (2010:26) indikator dari nilai disiplin adalah : "1) membiasakan hadir tepat waktu; 2) membiasakan mematuhi aturan; dan 3) menggunakan pakaian sesuai dengan ketentuan" dan menurut syafrudin (muhammad khafid dan suroso, 2007:91) adalah: "1) ketaatan terhadap waktu belajar; 2) ketaatan terhadap tugas-tugas pelajaran; 3) ketaatan menggunakan waktu datang dan pulang". Hasil penelitian menunjukan bahwa implementasi pendidikan karakter disiplin di SD N 187/1 Teratai muara bulian terlaksana dengan cukup. Hasil yang didapatkan terkait dengan indikator nilai disiplin.
\end{abstract}

Kata kunci: pendidikan karakter, karakter disiplin, Peserta Didik 


\section{PENDAHULUAN}

Hasil penelitian Nuriyatun (2016) mengenai implementasi pendidikan karakter disiplin dan tanggung jawab di SD Negeri 1 Bantul menunjukan bahwa implementasi pendidikan karakter displin dan tanggung jawab di SD Negeri 1 Bantul meliputii 3 aspek yaitu perencanaan, pelaksanaan, dan evaluasi.

Penelitian yang dilakukan oleh Nuriyatun (2016) meneliti mengenai implementasi pendidikan karakter disiplin dan tanggung jawab di Sekolah Dasar, sedangkan penelitian yang akan peneliti lakukan hanya mengenai implementasi pendidikan karakter disiplin di Sekolah Dasar.

Selanjutnya hasil penelitian Margono (2016) menegenai implementasi pendidikan karakter displin di MTs AlIkhsan Beji Kecamatan Kedungbanteng Kabupaten Banyumas menunjukan bahwa proses pendidikan karakter disiplin pada peserta didik MTs Al-Ikhsan melalui beberapa cara, yaitu keteladanan, pembiasaan, penglondisian.

Penelitian yang dilakukan oleh Margono (2016) sama dengan penelitian yang akan peneliti lakukan yaitu mengenenai implementasi pendidikan karakter disiplin, hanya saja jenjang pendidikan yang diteliti berbeda jika Margono melakukan penelitian di MTs sedangkan peneliti akan melakukan penelitian di Sekolah Dasar

Karakter merupakan sikap alami yang ada pada diri seseorang yang membedakan dengan orang lain. "Karakter ialah kualitas, kekuatan mental, moral, akhlak atau budi pekerti individu yang merupakan kepribadian khusus, yang menjadi pendorong dan penggerak, serta membedakan dengan individu lain" (Wiyani, 2013:25). Seseorang dikatakan berkarakter apabila berhasil menyerap nilai karakter yang dikehendaki masyarakat. Untuk itu, sangat penting membentuk manusia yang memiliki karakter yang baik. Pembentukan karakter dapat ditempuh melalui pendidikan karakter. Sejalan dengan UU No. 20 Tahun 2003 tentang Sisdiknas pasal 3 dengan adanya pendidikan karakter diharapkan peserta didik dapat mengembangkan kemampuannya sehingga nantinya bisa menjadi manusia yang bertaqwa, jujur, adil, tanggung jawab, disiplin, kreatif, mampu bekerja sama dan erwawasan. Untuk itu, pentingnya pendidikan karakter bagi peserta didik. Sejalan pula dengan pendapat Rosikum (2018) penanaman pendidikan karakter sejak dini merupakan harga paling mahal yang perlu, serta dengan memiliki karakter anak akan mampu menghiasi perbuatannya yang baik berlandasan nilainilai religiusitas.

Pendidikan karakter adalah proses pemberian, penanaman, serta pembentukan karakter yang dilakukan guru untuk peserta didik. Pendidikan karakter menjadi pondasi utama dalam membangun karakter bangsa. Mengingat banyak anak-anak saat ini yang masih dini, namun karakternya sudah rusak. Salah satu cara untuk memperbaikinya yaitu melalui pendidikan, baik itu pendidikan formal maupun pendidikan informal. Pendidikan informal bisa diperoleh dari lingkungan terdekat yaitu keluarga. Sedangkan pendidikan formal diperoleh di lembaga pendidikan di sekolah. Sekolah saat ini berbasis Kurikulum 2013, Kurikulum ini lebih menekankan penanaman aspek sikap atau karakter kepada peserta didik. Sejalan dengan pendapat Nasiruddin (2018) bahwasanya ada lima nilai utama karakter bangsa yang harus ditanamkan kepada anak, nilai tersebut adalah relegius, nasionalis, mandiri, gotong royong, dan intergritas.

Nilai-nilai karakter yang harus dikembangkan yaitu nilai karakter dalam kompetensi inti sikap spritual dan kompetensi inti sikap sosial yang terdapat di dalam Permendikbud No. 24 Tahun 2016. Diantara kedua kompetensi inti tersebut, penelitian ini hanya mengambil kompetensi inti sikap sosial. Kompetensi inti sikap sosial "menunjukkan perilaku jujur, disiplin, tanggung jawab, santun, peduli, dan percaya diri dalam berinteraksi dengan keluarga, teman dan guru" Diantara nilai-nilai karakter yang telah disebutkan, dalam (Permendikbud No. 24 Tahun 2016), Penelitian peneliti hanya difokuskan pada nilai karakter disiplin. 
Kemendiknas

(2010:9)

mendeskripsikan disiplin sebagai "tindakan yang menunjukkan perilaku tertib dan patuh pada berbagai ketentuan dan peraturan". Sedangkan menurut Maman Rachman (Tulus Tu'u, 2004:35) menjelaskan bahwa "disiplin berkenaan dengan pengendalian diri seseorang terhadap aturan". Berdasarkan pengertian di atas, maka dapat disimpulkan bahwa hakikat dari nilai disiplin ialah perilaku individu yang menunjukkan pada ketaatan pada sebuah aturan tertentu dan apabila melanggarnya akan dikenakan sanksi yang berlaku.

Dalam pendidikan, disiplin memiliki fungsi penting untuk ditanamkan pada peserta didik, sehingga akan tercapai perkembangan sikap sosial dan hasil belajar peserta didik. Karakter disiplin pada peserta didik akan terlihat melalui perbuatan serta tindakan yang dilakukan dalam rutinitasnya sehari-hari di sekolah. Menurut Tulus Tu'u (2004:38-44), mengemkakan bahwa fungsi disiplin adalah : "a) menata kehidupan bersama; b) membangun kepribadian; c) melatih kepribadian yang baik; d) pemaksaan; e) menciptakan lingkungan yang kondusif'. Kelima fungsi tersebut apabila dapat diterapkan dan ditambah dengan dukungan yang baik maka akan mencapai hasil yang diharapkan.

Menurut Kemendiknas (2010:26) indikator dari nilai disiplin adalah : "1) membiasakan hadir tepat waktu; 2) membiasakan mematuhi aturan; dan 3) menggunakan pakaian sesuai dengan ketentuan". Sedangkan menurut Syafrudin (Muhammad Khafid dan Suroso, 2007:91) adalah: "1) ketaatan terhadap waktu belajar; 2) ketaatan terhadap tugas-tugas pelajaran; 3) ketaatan menggunakan waktu datang dan pulang".

Penerapan nilai karakter disiplin dapat dilakukan di dalam berbagai rutinitas di lingkungan peserta didik. Salah satunya di lingkungan sekolah, di mana sebagian besar waktu yang dihabiskan peserta didik banyak di lingkungan sekolah. Lingkungan sekolah sangat mempengaruhi terbentuknya karakter peserta didik, baik itu kegiatan yang berkaitan dengan pembelajaran maupun kegiatan di luar jam pelajaran. SD
Negeri No.187/1 Teratai merupakan salah satu sekolah yang baru menerapkan Kurikulum 2013 pada peserta didik kelas I, III, IV, dan V pada tahun ajaran 2018/2019. Penerapan Kurikulum 2013 dilakukan bertahap, hal ini dilakukan agar penerapan Kurikulum 2013 dapat berjalan sesuai yang diharapkan. Hal ini diperoleh dari kinerja kepala sekolah serta tenaga pendidik yang profesional,

Berdasarkan hasil observasi di SD Negeri No.187/1 Teratai, berbagai program kegiatan yang dirancang dan dilaksanakan di sekolah tersebut, hal ini dilakukan untuk membentuk peserta didik yang berkarakter. Sekolah tersebut komitmen membangun budaya karakter, hal ini dilihat dari visi dan misi utama sekolah yaitu ingin menciptakan peserta didik yang cerdas, terampil, berbudaya berdasarkan iman dan takwa serta berwawasan peduli lingkungan. Adapun program kegiatan yang dilaksanakan untuk membentuk nilai karakter di sekolah tersebut, salah satunya nilai karakter disiplin, pelaksanaannya seperti guru menunggu peserta didik di depan pintu gerbang kelas, sebelum memasuki kelas dilakukan kegiatan membersihkan lingkungan sekolah serta memeriksa kebersihan di dalam kelas.

Berdasarkan latar belakang masalah, terdapat suatu yang menarik untuk diteliti, karena memang kenyataannya selain nilai religius yang menjadi pondasi utama yang wajib ditanamkan. Sikap sosial disiplin yang harus ditekankan, ditanamkan dan dibiasakan dalam rutinitas peserta didik di lingkungan sehari-hari. Untuk itu, peneliti ingin mengetahui lebih jauh penerapan pendidikan karakter disiplin yang dilaksanakan di sekolah dengan mengadakan penelitian yang berjudul "Implementasi Pendidikan Karakter Disiplin peserta didik di SD Negeri No. 187/1 Teratai”.

\section{METODE}

\section{Tempat dan Waktu Penelitian}

Penelitian ini dilakukan di SD Negeri 187/1 Teratai. Tempat penelitian ini berada di Kelurahan Teratai Kecamatan Muara Bulian Kabupaten Batanghari 
Provinsi Jambi. Waktu penelitian dilaksanakan bulan 21 Agustus sampai 28 September pada semester ganjil 2019/2020.

\section{Pendekatan dan Jenis Penelitian}

Penelitian ini menggunakan pendekatan penelitian kualitatif. Penelitian kualitatif yang didefinisikan oleh Bodgan dan Taylor (dalam Moleong, L. J, 2007:4) menyatakan bahwa penelitian kualitatif menghasilkan data deskriptif berupa katakata yang tertulis atau lisan dari orangorang dan perilaku yang dapat diamati. Berdasarkan pendapat ahli tersebut, peneliti menggunakan pendekatan penelitian kualitatif dalam melaksanakan penelitian.

Jenis penelitian ini adalah penelitian deskriptif. Hal ini sesuai dengan pendapat Bodgan dan Biklen (Moleong, L. J, 2007: 3) yang mengemukakan ada beberapa istilah yang digunakan dalam penelitian kualitatif, yaitu penelitian atau inkuiri naturalistik atau alamiah, etnografi, interaksionis simbolik, perspektif ke dalam, etnometodologi, the Chicago School, fenomenologis, studi kasus, interpretative, ekologis, dan deskriptif. Berdasarkan pendapat yang diungkapkan Bodgan dan Biklen tersebut, maka penelitian ini termasuk dalam jenis penelitian deskriptif. Jenis penelitian ini dipilih untuk mendeskripsikan implementasi pendidikan karakter disiplin pada peserta didik SD Negeri 187/1 Teratai.

\section{Data dan Sumber Data}

\section{Data}

Adapun sumber data dalam penelitian ini yaitu dibagi menjadi dua, yaitu data primer dan data skunder.

a. Data Primer

Data primer adalah data yang diperoleh langsung dari sumbernya tanpa ada perantara. (Mukhtar, 2009: 86). Data primer yang penulis maksudkan disini adalah dari hasil wawancara dan observasi mengenai implementasi pendidikan karakter disiplin SD Negeri 187/1 Teratai

b. Data Sekunder
Data sekunder adalah data yang diambil secara tidak langsung atau bersumber dari tangan kedua. (Sudjiono, A, 2006). Data sekunder dalam penelitian ini adalah data yang diambil dari SD Negeri 187/1 Teratai Kecamatan Muara Bulian Kabupaten Batanghari mengenai :

a. Struktur organisasi

b. Keadaan guru dan peserta didik

c. Keadaan sarana dan prasarana

d. Historis dan geografis.

\section{Sumber Data}

Sumber data yang diambil dalam penelitian ini yaitu sebagai berikut :

a. Data kepala sekolah

b. Data guru

c. Data peserta didik

\section{Teknik Pengambilan Sampel}

Teknik pengambilan sampel dalam penelitian ini yaitu Purposive Sampling. Menurut Mason dan patton (Setyosari, 2016:71) Purposive sampling adalah pemilihan sampel yang di sesuaikan dengan maksud atau tujuan penelitian yang akan dilakukan.Sejalan dengan hal itu sugiyono ( 2016:300) mengemukakan bahwa "Pengambilan sampel dalam penelitian kulitatif berfungsi untuk mendapatkan informasi dari orang yang dianggap paling tahu tentang data yang diinginkan". Berdasarkan teori tersebut, maka Purposive sampling dalam penelitian ini di gunakan untuk menentukan informan atau subjek penelitian.

\section{Teknik Pengumpulan Data}

Pada penelitian ini, teknik pengumpulan data yang di gunakan yaitu teknik observasi dan teknik wawancara (interview).

\section{Observasi}

Observasi atau yang sering di sebut dengan pengamatan merupakan kegiatan untuk mengetahui gambaran awal untuk pertama kali dalam penelitian. Selain itu tujuan dari observasi itu sendiri untukmengamati seluruh kegiatan atau aktivitas setiap peserta didik dalam proses pembelajaran. Observasi di lakukan 
menggunakan lembar instrument observasi yang telah disusun oleh peneliti dengan gambaran tentang pendidikan karakter point disiplin di sekolah dan di kelas saat pembelajarn.

Observasi yang digunakan adalah observasi non partisipan, dimana si peniliti tidak ikut serta dalam proses pembelajaran dan hanya sebagai pengamat objek yang menjadi yang menjadi penelitian. Observasi yang di lakukan hanya di kelas IV SD N187/1 Teratai.

\section{Wawancara}

Wawancara dalam penelitian dilakukan untuk mengetahui dan mencari informasi yang melalui hasil tanya jawab dengan sumber informasi secara langsung. Selain itu wawancara juga dapat mengungkapkan bagaimana sebenarnya yang terjadi dalam pendidikan karakter di SD Negeri 187/1 Teratai.

Wawancara yang digunakan adalah wawancara terstruktur, dimana wawancara yang dilaksanakan secara terencana dengan berpedoman dengan daftar pertanyaan yang telah disusun sebelumnya. Wawancara dilakukan oleh peneliti kepada guru kelas dan kepala sekolah di SD Negeri 187/1 Teratai.

\section{Instrumen Wawancara dan Observasi :}

\section{Pedoman Wawancara Kepala SD Negeri 187/1 Teratai}

\begin{tabular}{|c|l|l|}
\hline No & \multicolumn{1}{|c|}{ Pertanyaan } & Jawaban \\
\hline 1. & $\begin{array}{l}\text { Bagaimana } \\
\text { kedisiplinan peserta } \\
\text { didik di SD Negeri } \\
187 / 1 \text { Teratai? }\end{array}$ & \\
\hline 2. & $\begin{array}{l}\text { Apa saja problem } \\
\text { yang dihadapi oleh } \\
\text { pihak sekolah dalam } \\
\text { penanaman } \\
\text { kedisiplinan peserta } \\
\text { didik di SD Negeri } \\
187 / 1 \text { Teratai? }\end{array}$ & \\
\hline 3. & $\begin{array}{l}\text { Jika ada peserta didik } \\
\text { yang melanggar } \\
\text { peraturan sekolah, } \\
\text { konsekuensi apa yang } \\
\text { diterima peserta didik }\end{array}$ \\
\hline
\end{tabular}

\begin{tabular}{|l|l|l|}
\hline & $\begin{array}{l}\text { di SD Negeri 187/1 } \\
\text { Teratai? }\end{array}$ & \\
\hline 4. & $\begin{array}{l}\text { Factor apa saja yang } \\
\text { mempengaruhi } \\
\text { penanaman } \\
\text { kedisiplinan peserta } \\
\text { didik di SD Negeri }\end{array}$ \\
\hline 5. & $\begin{array}{l}\text { Bagaimana cara upaya } \\
\text { sekolah } \\
\text { meningkatkan untuk } \\
\text { kedisiplinan peserta } \\
\text { didik di SD Negeri } \\
187 / 1 \text { Teratai }\end{array}$ \\
\hline 6. & $\begin{array}{l}\text { Bagaimana anatara } \\
\text { komunikasi antara } \\
\text { orang tua dengan } \\
\text { pihak sekolah dalam } \\
\text { kedisiplinan peserta } \\
\text { didik di sekolah? }\end{array}$ \\
\hline
\end{tabular}

Tabel 1.1 wawancara kepala sekolah

Pedoman Wawancara Wali Kelas SD Negeri 187/1 Teratai

\begin{tabular}{|c|l|l|}
\hline No & \multicolumn{1}{|c|}{ Pertanyaan } & Jawaban \\
\hline 1. & $\begin{array}{l}\text { Bagaimana dan } \\
\text { pendekatan pembelajaran } \\
\text { metode gunakan } \\
\text { yang Ibu pembelajaran } \\
\text { saat di dengan } \\
\text { yang Ibu lakukan di } \\
\text { kelas? }\end{array}$ & \\
\hline 2. & $\begin{array}{l}\text { Apakah dan } \\
\text { pendekatan } \\
\text { metode yang Ibu } \\
\text { gunakan } \\
\text { mendapatkan respons } \\
\text { yang positif dari } \\
\text { peserta didik? }\end{array}$ \\
\hline 3. & $\begin{array}{l}\text { Bagaimana cara yang } \\
\text { Ibu gunakan untuk } \\
\text { mengembalikan } \\
\text { semangat belajar } \\
\text { terhadap } \\
\text { pembelajaran? }\end{array}$ & \\
\hline 5. & $\begin{array}{l}\text { Apakah Ibu selalu } \\
\text { memberikan teladan } \\
\text { yang baik kepada } \\
\text { peserta didik? }\end{array}$ & \\
\hline 6. & $\begin{array}{l}\text { Apakah Ibu selalu } \\
\text { mengawasi dan } \\
\text { mengontrol } \\
\text { kedisiplinan peserta } \\
\text { didik? } \\
\text { Apa yang Ibu lakukan }\end{array}$ & \\
\hline 7. & \\
\hline
\end{tabular}


jika peserta didik Ibu tidak disiplin waktu?

Tabel 1.2 wawancara guru kelas.

\section{Pedoman Observasi}

\begin{tabular}{|c|c|c|c|c|c|}
\hline No & Indkikator & 1 & 2 & 3 & 4 \\
\hline 1. & $\begin{array}{l}\text { Kondisi } \\
\text { pembelajaran } \\
\text { secara kondusif }\end{array}$ & & & & \\
\hline 2. & \begin{tabular}{lr}
\multicolumn{2}{l}{ Menyelesaikan } \\
tugas & sesuai \\
waktu & yang \\
ditetapkan &
\end{tabular} & & & & \\
\hline 3. & $\begin{array}{lr}\text { Masuk } & \text { sekolah } \\
\text { secara } & \text { tepat } \\
\text { waktu } & \\
\end{array}$ & & & & \\
\hline 4. & $\begin{array}{lr}\text { Pulang } & \text { sekolah } \\
\text { secara } & \text { tepat } \\
\text { waktu } & \\
\end{array}$ & & & & \\
\hline 5. & \begin{tabular}{lr}
\multicolumn{2}{l}{ Menyelesaikan } \\
tugas & sesuai \\
waktu & yang \\
ditetapkan & \\
\end{tabular} & & & & \\
\hline 6. & $\begin{array}{l}\text { Berpakaian } \\
\text { sesuai dengan } \\
\text { peraturan }\end{array}$ & & & & \\
\hline
\end{tabular}

Tabel 1.3 pedoman observasi

Keterangan :

4 : berarti "sesuai"

3 : berarti "cukup sesuai"

2 : berarti "kurang sesuai"

1 : berarti "tidak sesuai"

\section{Uji Validitas}

Uji validitas data ini digunakan sebagai mengukur tingkat kesahihan dari sebuah data. Data dikatakan valid apabila derajat ketepan antara data yang terjadi pada objek penelitian sesuai dengan data yang diperoleh oleh peneliti. Uji validitas data dapat dilakukan dengan berbagai cara yaitu berupa perpanjang pengamatan, peningkatan ketentuan, triangulasi, diskusi bersama teman, analisis kasus negatif, dan member check (Sugiono, 2016:368). Dalam penelitian peneliti menggunakan triangulasi untuk menguji keabsahan data.

\section{Triangulasi Teknik}

Triangulasi teknik adalah suatu teknik yang dilakukan dengan menggunakan berbagai teknik. Pengumpulan data yang berbeda untuk mendapatkan data dari sumber yang sama. Teknik yang dilakukan oleh peneliti berupa studi pendahuluan tujuannya adalah untuk mengetahui objek yang akan diteliti, kemudian dilakukan observasi dan wawancara bersama dengan guru kelas dan kepala sekolah untuk mengetahui pendidikan karakter kedisiplinan peserta didik sekolah dasar kelas IV SD N 187/I Teratai.

\section{Triangulasi Sumber}

Triangulasi sumber dilakukan dengan cara mengecek data yang telah diperoleh melalui beberapa sumber. Dalam penelitian ini peneliti melakukan pengecekan data yang diperoleh dari hasil wawancara guru kelas dan observasi mengenai pendidikan karakter kedisiplinan peserta didik.

\section{Teknik Analisis Data}

Bogdan (Sugiyono, 2015: 334) analisis data kualitatif adalah proses mencari dan menyusun secara sistematis data yang diperoleh dari hasil wawancara, catatan lapangan, dan bahan-bahan lain, sehingga dapat mudah difahami, dan temuannya dapat diinformasikan kepada orang lain.

Analisis data dilakukan dengan mengorganisasikan data, menjabarkannya ke dalam unit-unit, melakukan sintesa, menyusun ke dalam pola, memilih mana yang penting dan yang akan dipelajari, dan membuat kesimpulan yang dapat diceritakan kepada orang lain.

Penelitian ini mengacu pada konsep Miles and Huberman (Sugiyono, 2015: 337) mengemukakan bahwa aktivitas dalam analisis data kualitatif dilakukan secara interaktif dan berlangsung secara terus menerus sampai tuntas, sehingga datanya sudah jenuh. Aktivitas dalam analisis data, yaitu data reduction, data display, dan conslusion drawing/verification. 
Langkah-langkah penelitian ini ditunjukkan pada gambar sebagai berikut:



2.1 bagan langkah penelitian

\section{Reduksi Data (Data Reduction)}

Mereduksi data berarti merangkum, memilih hal-hal yang pokok, memfokuskan pada hal-hal yang penting, dicari tema dan polanya dan membuang yang tidak perlu (Sugiyono, 2015: 338). Dalam mereduksi peneliti memilah-milah data, merangkum, mengambil data yang pokok dan penting, dan membuat kategorisasi. Kemudian peneliti dalam melakukan reduksi data mengacu pada tujuan yaitu temuan.

\section{Penyajian Data (Data Display)}

Setelah mereduksi data langkah selanjutnya yang harus dilakukan adalah mendisplaykan data. Melalui penyajian data, data terorganisasikan, tersusun dalam pola hubungan, sehingga akan semakin mudah dipahami (Sugiyono, 2015: 341). Penyajian data ini dapat dilakukan dalam bentuk uraian singkat, bagan, hubungan antar kategori, dan sejenisnya. Kemudian dari penyajian data tersebut dapat memberikan adanya penarikan kesimpulan dan verifikasi yang mengarah pada tercapainya tujuan penelitian.

3. Penarikan Kesimpulan (Conclusion Drawing/Verification)

Langkah selanjutnya dalam analisis data setelah menyajikan data yaitu penarikan kesimpulan dan verifikasi. Kesimpulan dalam penelitian kualitatif ini dapat menjawab rumusan masalah yang telah disampaikan namun masih bersifat sementara dan akan berkembang setelah penelitian berada di lapangan (Sugiyono. 2015: 345). Kemudian kesimpulan penelitian ini diharapkan ada temuan baru yang sebelumnya belum pernah ada. Temuan dapat berupa deskripsi atau gambaran suatu obyek yang sebelumnya masih remang-remang atau gelap sehingga setelah dilakukannya penelitian menjadi obyek yang jelas. Selain itu dapat berupa hubungan kausal atau interaktif, hipotesis atau teori.

\section{Prosedur Penelitian}

Penelitian ini dilaksanakan di kelas IV SD Negeri 187/1 Teratai. Setelah itu peneliti melakukan pemilihan sampel yang akan diteliti. Setelah sampel ditentukan, langkah selanjutnya adalah menetapkan fokus penelitian, yaitu mengenai implementasi pendidikan karakter disiplin peserta didik Sekolah Dasar, yang diikuti dengan persiapan instrumen penelitian berupa lembar wawancara terhadap kepala sekolah dan wali kelas, serta lembar observasi terhadap peserta didik.

Instrumen penelitian yang digunakan telah disesuaikan berdasarkan penelitian terdahulu. Pada bagian penelitian terdahulu telah dijelaskan bahwa, sebagian penenlitian menggunakan teknik pengumpulan data berupa wawancara dan observasi.

Setelah data terkumpulkan, maka dilakukan analisis data menggunakan model Miles and Huberman, dengan alur reduksi data, penyajian data, dan penarikan kesimpulan. Berdasarkan hasil analisi tersebut, maka diperolehlah informasi mengenai hasil penelitian ini. Adapun prosedur penelitian ini digambarkan ke dalam bagan berikut ini: 


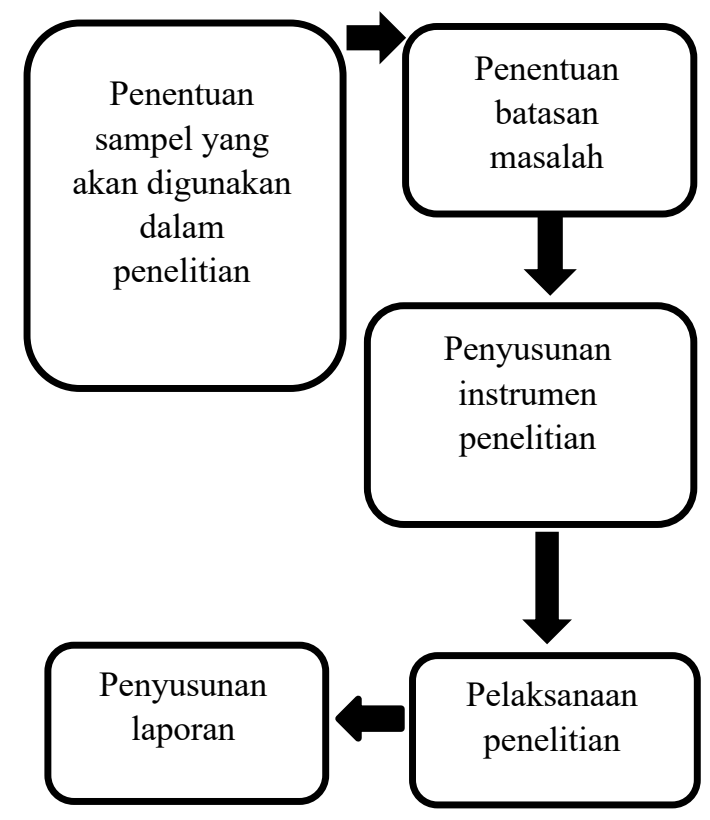

2.2 bagan prosedur penelitian

\section{HASIL DAN PEMBAHASAN}

Hasil wawancara Kepala Sekolah :

Kedisiplinan peserta didik di SD 187/1 Teratai cukup baik, karena peserta didik yang masih bisa diberi bimbingan mengenai kedisiplinan melalaui aturanaturan sekolah yang berlaku. Problem kedisiplinan yang ada di sekolah dasar 187/1 Teratai adalah keterlambatan untuk datang ke sekolah. Keterlambatan itu terjadi karena beberapa faktor, seperti peserta didik yang telat untuk bangun tidur, sehingga ia terlambat berangkat ke sekolah.

Ketika ada peserta didik yang melanggar aturan maka wali kelas lah yang memberikan sanksi berupa memungut sampah yang ada di lingkungan sekolah. Faktor yang mempengaruhi kedesiplinan di sekolah SD Negeri 187/1 Teratai yaitu fakor internal yang berasal dari diri peserta didik itu sendiri, selain itu faktor eksternal berupa dorongan dari orang tua sangat mempengaruhi kedisiplinan siswa di sekolah.

Upaya yang dilakukan sekolah untuk meningkatkan kedisiplinan peserta didik berupa memberi penguatan mengenai nilainilai disiplin yang harus dimiliki siswa, seperti harus datang tepat waktu, serta berpakaian yang rapi. Komunikasi antara orang tua dengan pihak sekolah dalam kedisiplinan peserta didik berjalan baik, guru dan orang tua bekerja sama dalam membentuk kedisiplinan peserta didik.

Hasil wawancara Wali Kelas.

Pendekatan dan metode pembelajaran yang digunakan oleh Ibu Rabiah selaku wali kelas saat pembelajaran yaitu pendekatan saintifik sesuai dengan kurikulum 2013 yang sudah diterapkan di SD 187/1 Teratai serta meggunakan metode ceramah dan diskusi. Dengan menggunakan metode dan pendekatan tersebut peserta didik memberikan repons yang positif dalam pembelajaran.

Cara yang digunakan oleh wali kelas untuk untuk mengembalikan semangat belajar peserta didik dalam pembelajaran yaitu dengan mengajak peserta didik untuk menyanyi dan bermain games disela-sela pembelajaran untuk membangkitkan semngat peserta didik.

Ibu Rabiah selaku wali kelas selalu memberikan contoh teladan yang baik bagi peserta didik, misalnya dengan berpakaian rapi dan masuk kelas tepat waktu. Sehingga peserta didik akan termotivasi selalu berpakaian rapi dan masuk kelas tepat waktu. Mengawasi dan mengontrol kedisiplinan peserta didik dilakukan oleh wali kelas seperti ketika ada peserta didik yang terlambat masuk kelas maka dibei teguran, ketika peserta didik tidak menyelesaikan pekerjaan rumah dengan tepat waktu maka diberikan sanksi.

Hasil observasi

Kondisi pembelajaran di sekolah sudah cukup terlihat ketika bel berbunyi peserta didik memasuki kelas dengan teratur. Saat pembelajaran peserta didik memperhatikan penjelasan guru dengan baik. Tugas yang berikan guru kepada peserta didik dapat diselesaikan dengan baik, namun ada dua peserta didik yang terlambat dengan pengumpulan tugasnya. Keterlambatan peserta didik dalam mengumpulkan tugas akan diberikan sanksi yang berupa membawa pot bunga untuk di bawa kesekolah. Dengan adanya bel 
sekolah masuk dan pulang sekolah terjadi tepat waktu. Pakaian yang digunakan oleh peserta didik sesuai dengan aturan yang ditetapkan sekolah.

\section{KESIMPULAN}

Berdasarkan hasil penelitian yang dilakukan oleh peneliti dapat diperoleh kesimpulan bahwa kedisiplinan di SD N 187/1 Teratai muara bulian telah terlaksana dengan baik. Kedisiplinan dapat dilihat dari patuhnya peserta didik dalam mengimplementasikan aturan sekolah yang berlaku di sekolah. Sedikitnya peserta didik yang melanggar aturan yang barlaku. Dan jika melanggar aturan terdapat sanksisanksi yang berlaku di sekolah tersebut baik dari guru kelas maupun guru piket di sekolah. Sanksi yang di peroleh oleh peserta didik berupa sanksi yang mash dalam kategori mendidik. Tujuan semua dilakukan agar peserta didik menjadi lebih baik lagi.

Memuat kesimpulan penelitian yang singkat dan jelas. Jika ada sertakan saransaran yang muncul sebagai akibat dari hasil kajian atau penelitian yang telah dilakukan. Saran dituliskan setelah paragraf yang memuat kesimpulan, tidak dituliskan menjadi bagian yang terpisah. Kesimpulan maupun Saran (jika ada) disampaikan dalam bentuk paragraf bukan poin-poin. Huruf TNR 11.

\section{DAFTAR PUSTAKA}

Hartati, Welly. 2017. Implementasi Pendidikan Karakter Disiplin di SD Negeri 7 Tanjung Raja. Artikel. Kepala sekolah SD Negeri 26 Tanjung raja.

Margono, Tri. 2016. Implementasi Pendidikan karakter Disiplin di MTs Al-Ikhsan Beji Kecamatan
Kedungbanteng
Banyumas.
Kabupaten
Purwokerto.
Skripsi.
IAIN

Nasariddin. 2018. Pembentukan karakter anak melalui keteladanan orang tua. http://jurnalkependidikan.iainpurwok erto.ac.id. Vol.6 (2) 323-333.

Nuriyatun, Puji Dwi. 2016. Implementasi Pendidikan Karakter Disiplin dan Tanggung Jawab di SD Negeri 1 Bantul. Skripsi. Universitas Negeri Yogyakarta.

Panduan Penulisan Skripsi Universitas Jambi. 2018. FKIP Universitas Jambi

Patmawati, Sri. 2018. Penerapan Pendidikan Karakter Disiplin Dan Tanggung Jawab Siswa di SD Negeri No. 13/1 Muara Bulian. Skripsi. FKIP Uniersitas Jambi.

Prasetya, Alfian Budi. 2014. Penerapan Pendidikan Karakter Nilai Disiplin dan Nilai Tanggung Jawab dalam Mata Pelajaran Pendidikan Jasmani, Olahraga, dan Kesehatan (PJOK) di kelas I dan IV SD Negeri Percobaan 3. Skripsi. Universitas Negeri Yogyakarta.

Putri, Dini Palupi. 2017. Pendidikan Karakter pada Anak Sekolah Dasar di Era Digital. Artikel. Institut Agama Islam Negeri (IAIN) Curup.

Rosikum, 2018. Peran Keluarga dalam Implementasi Pendidikan Karakter Religius Anak. http://jurnalkependidikan.iainpurwok erto.ac.id. Vol. 6 (2) 293-308.

Sukiman. 2017. Praktik Baik Pelibatan Keluarga. Jakarta: Kementrian Pendidikan dan Kebudayaan. 